\title{
Staff perceptions of the success of an alternative curriculum: Skill
}

\section{Force}

Susan Hallam, Institute of Education, University of London

Lynne Rogers, Open University

Jasmine Rhamie, University of Southampton

Contact: Professor Susan Hallam, Institute of Education, University of London, 20

Bedford Way, London, WC1H OAL

E-mail: s.hallam@ioe.ac.uk

Telephone 02076126371 


\title{
Staff perceptions of the success of an alternative curriculum:
}

\section{Skill Force}

\begin{abstract}
This paper describes staff perceptions of the implementation of an alternative curriculum, Skill Force, for disaffected pupils in the UK. The perceptions of Skill Force and school staff were compared based on data from questionnaires completed by 62 Skill Force and 84 school staff and interviews with representative samples of each. While the data indicated that the programme had been successful in re-engaging the students with education, the improvement was more marked in relation to the Skill Force programme than the wider school context.
\end{abstract}




\section{Staff perceptions of the success of an alternative curriculum:}

\section{Skill Force}

\section{Introduction}

At any one time a substantial proportion of young people are not in mainstream education, are receiving 'education otherwise' or have poor levels of attendance (Social Exclusion Unit, 1998). In the long term persistent truants and those who are excluded from school tend to have lower status occupations, less stable career patterns and greater unemployment in comparison with others sharing similar backgrounds (Hibbett and Fogelman, 1990a; 1990b). Some, but not all may be involved in delinquency (Audit Commission, 1996; Cullingford, 1999). Positive relationships between attendance at school and academic performance further indicate that reducing exclusion and improving attendance are crucial for the individual pupil and society as a whole (DfES 2002).

Attempts to improve attendance at school since national statistics have been available have had mixed results. In maintained secondary schools between 1995/96 and 2007/08 the percentage of authorised absence reduced from $8.4 \%$ in $1995 / 96$ to $5.87 \%$ in $2007 / 08$ (measured as a percent of half day sessions missed). However, unauthorised absence rose slightly from around $1 \%$ in most years to $1.49 \%$ in 2007/08. (DCSF, 2009a). Recently, the DCSF has reported statistics on Persistent Absentees (PAs) (having more than 63 sessions of absence during the year). In secondary schools this accounted for 5.6\% of enrolments. The average rate of overall absence for PAs in 2007/08 was 35\%, over five times the rate for all pupils. Schools vary considerably in the extent to which they maintain high levels of attendance even when they have similar catchment areas. Their procedures and ethos are 
implicated (Hallam et al., 2002), in particular, pupil teacher relationships (O'Keeffe, 1994). Teachers tend to see persistent absentees as lazy, lacking concentration, restless, and difficult to discipline (Farrington, 1980), while persistent absentees believe that they are picked on unfairly, not treated with respect, handled inconsistently and dealt with too harshly (Buist, 1980). While the school has an important role in promoting attendance, families also have a part to play. Evidence from 'truancy sweeps' suggests that parents often collude with their children in non-attendance at school. Improving attendance requires the adoption of a range of strategies including those involving parents and offering curricula which are seen as relevant and accessible (see Hallam, 1996, Hallam and Rogers, 2008).

The ultimate sanction for poor behaviour in school is exclusion. This can be fixed term or permanent. Anecdotal evidence suggests that exclusions also occur without regard to official procedures, where parents are asked to keep a child at home for a few days. The number of students excluded from school increased dramatically during the 1990s from 2910 in 1990/91 to 12,458 in $1995 / 6$. In the mid-1990s, the then Department for Education and Employment (DfEE) set up a series of projects which had the reduction of exclusion and indiscipline as their principle aim. They were successful in raising awareness of the importance of reducing exclusion and succeeded in slowing the rate of increase. Exclusion rates now appear to have stabilised with 8,130 children permanently excluded from school in 2007/08 (DCSF, 2009b). The highest rates of exclusion are for boys, pupils with Special Educational Needs and some minority ethnic groups. There is also a positive relationship between eligibility for free school meals and exclusion rates. Although schools with the highest rates of exclusion do not always have high rates of free school meal eligibility, they do tend to have higher proportions of pupils with Special Educational Needs and low levels of pupil attainment (DCSF, 2009). While the causes of exclusion are many and complex (Parsons, 1999; Munn et al., 2000; Osler 
et al., 2001), the reduction of exclusions depends on schools developing inclusive approaches to the curriculum and teaching, while also developing strategies for working with other agencies in supporting pupils who are at risk.

In recent years there have been a number of initiatives which have attempted to improve attendance and reduce exclusion. Skill Force, an independent charitable trust, is one such initiative. It aims to improve students' attitudes towards education and thus improve attendance and behaviour providing them with a range of vocational qualifications which will raise career aspirations, lead to continuation in full time education, encourage the take up of apprenticeships, or lead to full time employment. The considerable experience and skills of former service personnel and others are used to deliver a range of alternative curricula activities for 14-16 year olds. Skill Force started as a pilot scheme in Newcastle and Norfolk in 2000 and now has teams spread throughout the United Kingdom instructing about 7,000 young people. The programme offers a wide range of activities which focus on team building, problem solving, and raising self-esteem through the teaching of programmes such as the Duke of Edinburgh's Award scheme. The military systems approach to training of the instructors enables them to deliver a course that is practical, flexible and relevant.

Students selected for Skill Force typically drop two GCSE subjects. The programme takes place within school hours and operates under school rules. The curriculum was devised in conjunction with senior teachers and provides a course based around work related learning that future employers recognise. The core is the ASDAN key skills award but other awards, certificates and qualifications such as the Duke of Edinburgh Award, St John's Ambulance Young Lifesavers Certificate and the OCR Certificate in Preparation for Employment are offered. The emphasis is on learning in practical situations. Students are given responsibility for their learning and the opportunity to make choices. The teams offer a range of activities 
typically including residential trips, sports, outdoor pursuits, community/environmental projects and classroom work. Students are also taught a range of practical life skills.

The research reported here is derived from an extensive evaluation of Skill Force. This paper focuses on the differences in perceptions of teachers and Skill Force personnel on the impact of the programme on the participating students. Students' perceptions of the impact of the programme are reported elsewhere as are the actual data relating to attendance and exclusions (see Hallam et al., 2007).

\section{Methodology}

Data were collected from a range of sources. Questionnaires were developed to be administered to all students, Skill Force instructors and Team Leaders, and school staff who had a role in liasing with Skill Force personnel. These included open questions and rating scales designed to assess the impact of Skill Force on students' motivation, confidence, attitudes towards school, behaviour, exclusions, attendance, academic performance and future aspirations. The actual statements adopted in the questionnaires are set out in the findings section. Visits were made to six projects selected to represent different types of development of the programme. During these visits interviews were undertaken with, students, parents, school staff, and Skill Force personnel.

The findings are based on responses from 64 Skill Force staff and 82 members of school staff representing 18 centres and 56 schools. The school staff completing questionnaires included link teachers, assistant or deputy heads, senior teachers, year and curriculum managers, head teachers and learning support teachers. 


\section{Findings}

\section{Perceived impact on motivation and attitudes towards school}

Skill Force personnel and school staff were asked to respond to a number of statements regarding pupils' motivation and attitudes towards school. The statements, levels of agreement with them, and statistical data relating to the differences in responses between school and Skill Force staff are set out in Table 1. Overall, 92\% of Skill Force staff and 89\% of school staff believed that Skill Force had been at least quite successful in improving motivation towards school while $100 \%$ of Skill Force staff and $88 \%$ of school staff indicated similar levels of agreement in relation to success in engendering positive attitudes towards school. In relation to changing student perceptions of the value of education $97 \%$ of Skill Force staff and $88 \%$ of school staff indicated that Skill Force had been at least quite successful.

The rating scale data were supported by staff responses to the open questions and the data derived from the interviews. The instructors recognised that they were working with students whose motivation was generally very low for a range of reasons. They aimed to increase motivation by providing opportunities for success, and giving students choice and responsibility:

It gives the students a different way of looking at things. Kids are disillusioned and bored and it gives them opportunities they wouldn't otherwise get. (Instructor) 
The students often had impoverished backgrounds and instructors noted that that they tended to have 'no aspirations and low expectations.' Adopting simple behaviourist approaches Skill Force staff managed behaviour and improved motivation. Rewards were offered for good behaviour, for instance, a game of football or a trip. Teachers indicated that these benefits were felt across the curriculum:

Skill Force has given the kids a degree of self motivation and self awareness that has benefited them across the whole curriculum. (Teacher)

In other cases pupils motivated each other:

One group of boys worked very well together - they got their ASDAN bronze very quickly. They spurred the others on. (Instructor)

But the effects on motivation were not universal. In some pupils there was no change.

\section{Table 1 about here}

\section{Perceived impact on well-being, self-confidence and social skills}

Skill Force personnel and school staff indicated the extent of their agreement with statements relating to the well-being and confidence of the students. $95 \%$ of Skill Force staff and $89 \%$ of school staff believed that the programme had been at least quite successful in promoting the well-being of participating students, while $97 \%$ of Skill Force staff and $92 \%$ of school staff believed that the programme had achieved similar levels of success in raising self-confidence. Responses to the interviews and open questions supported the questionnaire data: 
There is a very positive impact on the raising of self-esteem, primarily amongst the boys. Boys tend to have very low self-esteem in this area, and the programme gives them different strategies to behave appropriately for different learning situations. (Deputy Head Teacher)

The questionnaires included a range of statements relating to pupils' social skills and relationships with others. $98 \%$ of Skill Force staff and $90 \%$ of school staff agreed that the programme had been at least quite successful in improving social skills while $99 \%$ of Skill Force staff and $82 \%$ of school staff indicated similar levels of agreement in relation to raising participating students' levels of respect for other people. Staff-pupil relationships were also believed to have improved (98\% Skill Force; 74\% school staff).

Skill Force staff were aware of the differences between their relationships with the students and those of the school staff. They explained these differences in relation to the contact that they had with the students for extended lengths of time; the credibility they had because they had life experiences outside education; and the approach they adopted which was trusting and non judgemental, working quietly and allowing the students to retain their dignity:

We talk to them quietly, and don't embarrass them in front of the class. That leads to conflict. We talk quietly to them if we need to, by their side, or outside. (Instructor)

The development of positive relationships with students enabled Skill Force personnel to be able to adopt a counselling or mentoring role with students. This facilitated students sharing their problems with Skill Force staff: 
The kids confide in us about problems because we've got time for them, to sit and talk about what they did at the weekend, if their parents have just split up. We're emotional pillars for them. We're approachable but not soft touches. (Instructor)

However, Skill Force personnel were not always successful in breaking down barriers:

At XXX most of the kids are African-Caribbean. They don't open up in the same way and there are barriers because I'm white and they're Afro-Caribbean. I try to get to know the kids as individuals and see how they need to be talked to. (Instructor)

\section{Perceived impact on behaviour and exclusions}

$98 \%$ of Skill Force staff and $82 \%$ of school staff believed that the programme had been at least quite successful in improving behaviour in school, and $86 \%$ and $74 \%$ respectively out of school. Success in reducing detentions was viewed less positively. $81 \%$ of Skill Force personnel and $62 \%$ of school staff agreed that there had been at least some success. In relation to exclusions, $88 \%$ of Skill Force staff and $78 \%$ of school staff believed that the programme had been more than quite successful in reducing fixed term exclusions, and $92 \%$ and $72 \%$ respectively in relation to permanent exclusions (see Table 2).

\section{Table 2 about here}

When interviewed Skill Force personnel were cautious in assessing the impact of the programme on behaviour, although they were confident that as a result of participating in Skill Force students understood the consequences of poor behaviour. Skill Force staff reported that 
change took time and that in some cases there was no change, particularly in relation to pupils behaviour in other school lessons:

Their behaviour hasn't changed in all lessons but they do appear to be different in Skill Force lessons. I think it's because the structure and delivery are so different to mainstream curricula and therefore when students come in they know it's that pressure on them-a worksheet or something that's got to be done within 50 minutes, writing or something. Then they may get a reward. (Link Teacher)

Skill Force staff adopted a non-confrontational approach to dealing with students attempting to diffuse difficult situations. School staff noted the change:

'Even the most challenging of students have toned down their usual response to everyday situations they find themselves in, and are displaying significant changes in self-control.' (Senior Teacher)

\section{Management of discipline in the school}

$95 \%$ of Skill Force personnel and 52\% of school staff believed that the programme had been at least quite successful in increasing staff confidence in working with students participating in Skill Force (see Table 2). Some school staff commented positively on the impact of the programme in relation to their own well-being:

Staff morale has been raised as disciplinary matters and anti-social behaviour have been reduced. Students over whom staff despaired in Year 9 have achieved and become better 
people to the delight of all. (Head Teacher)

$89 \%$ of Skill Force staff and $67 \%$ of school staff believed that the programme had been at least quite successful in reducing management time spent on discipline matters for participating students. However, only 19\% of Skill Force and 14\% of school staff believed that the programme had had similar levels of success in reducing management time in school on discipline matters for all students (see Table 2).

\section{Perceived impact on attendance}

97\% of Skill Force staff and 79\% of school staff perceived that the programme had been at least quite successful in improving the attendance of participating pupils, while 95\% of Skill Force staff but only $72 \%$ of school staff thought that the programme had had similar levels of success in reducing unauthorised absence. In relation to punctuality, $98 \%$ and $67 \%$ respectively thought that the programme had been at least quite successful in relation to arriving at school and $93 \%$ and $64 \%$ in relation to lessons (see Table 2). One of the reasons for the differences in perceptions of the improvement in attendance and punctuality between Skill Force and school staff may have been because students were attending Skill Force classes but not others. However, it was acknowledged that for some pupils attendance at Skill Force represented a considerable achievement. This improvement was perceived to be the result of enjoyment of the Skill Force curriculum and the extent to which students were given responsibility.

\section{Perceived impact on school work and attainment}


In relation to improving concentration, $97 \%$ of Skill Force personnel and $76 \%$ of school staff believed that the programme had been at least quite successful. Greater levels of agreement were found in relation to improving communication skills (98\% of Skill Force staff and $87 \%$ of school staff believed that the programme had been at least quite successful), while $100 \%$ and $87 \%$ respectively believed that Skill Force had been at least quite successful in improving listening skills (see Table 3).

\section{Table 3 about here}

\section{Perceived impact on school performance and qualifications}

The programme was perceived as at least quite successful in raising the standard of participating pupil's work by $98 \%$ of Skill Force and $77 \%$ of school staff (see Table 3 ). The quality and quantity of work produced was commented upon in the interviews. The writing up process was particularly important in relation to the trips. The opportunity to gain qualifications was valued by the students and school staff:

It is extremely gratifying to see students receiving well earned certificates of achievement in such areas as life saving and first aid and that they are keen to continue this 'achievement process'. These rewards for success are a valuable contribution to the students feeling valued and valuing themselves. (Deputy Head)

Some school staff indicated that the success achieved in qualifications led to improved work in other areas. Generally, the programme was not viewed as having a major impact on improving GCSE grades, only $54 \%$ of Skill Force staff and 33\% of school staff felt that it had 
been at least quite successful, but it was seen as having an impact on improving career opportunities (94\% Skill Force, $78 \%$ school staff). It was also felt to be at least quite successful in raising career aspirations (98\% Skill Force; 72\% school staff). Skill Force instructors indicated that the students were increasingly employable because of the practical skills that they had developed and the qualifications and awards that they had gained.

\section{Perceived impact on school-home relationships}

The programme was perceived to have been at least quite successful in improving parent-teacher relationships by $75 \%$ of Skill Force staff and $62 \%$ of school staff and $82 \%$ and $68 \%$ respectively thought that the programme had had a similar impact in encouraging greater communication between school and home. Overall, the parents of participating students were very positive about the impact of Skill Force. Most believed that Skill Force had benefited their children, through developing more positive attitudes to school, improving behaviour, improving attendance at least for Skill Force, and enhancing their prospects. Skill Force personnel were anxious to develop good relationships with parents and contacted them to inform them of their children's successes. They also encouraged parents to contact them if there were problems.

\section{Discussion}

The main impact of Skill Force as perceived by staff was seen to be in relation to pupils' personal and social skills. Their motivation was perceived to have improved, the extent to which they valued education and their attitudes towards school. They were perceived to have higher levels of self-esteem and engagement with the programme was seen to have enhanced 
their well-being. There were also perceived improvements in the ability to work in teams, respect for others and the skills needed to undertake academic work, for instance concentration, listening and communication. These changes led to an a perceived improvement in behaviour and attendance, and a reduction in exclusions. The programme was perceived to have relatively little impact on GCSE performance, parent-teacher relationships, and the time spent in managing discipline across the whole school. Staff perceptions of the value of the programme were similar to those of the pupils themselves (see Hallam et al., in press). Overall, the programme provided a successful alternative to the National Curriculum for these disaffected pupils.

There were statistically significant differences in response to many of the statements between Skill Force personnel and school staff. There are two likely reasons for this. Firstly, the Skill Force personnel were evaluating their own work which is likely to have encouraged them to be more positive. Secondly, Skill Force and school staff were working with the participating students in very different contexts. Skill Force provided a curriculum more suited to the needs of the students with the possibility of the acquisition of qualifications which were perceived by the students to be of value in gaining employment. Groups were small enabling staff to get to know students and offer them support. Students were given choices about their work and behaviour was managed through a system of rewards. Relationships with Skill Force staff were good, and provided opportunities to discuss personal issues in a relatively non-judgemental context. The differences in responses between the two groups of staff can be explained largely in relation to these differing contexts and the responses of the students to them. 
Overall, the programme was perceived by staff to have been successful in helping participating, disaffected young people to re-engage with learning, and in providing clear progression routes to post-16 education, training or employment. The findings demonstrate the importance of providing an appropriate curriculum and motivational assessment procedures in stimulating enthusiasm for learning. They also indicate the need for a supportive, non-judgemental context. If we wish to improve attendance and reduce exclusions from school, and satisfy the aims of the Every Child Matters agenda enabling every child to be healthy, stay safe, enjoy and achieve, make a positive contribution and achieve economic well-being we must develop curricula, and ways of delivering them to meet the needs of all students, not only the needs of those who are already well accommodated in existing systems.

\section{References}

Audit Commission (1996) Misspent Youth, Young People and Crime (London: Audit Commission)

Buist, M. (1980). Truants talking. Scottish Educational Review, 12(1), pp. 40-51.

Cullingford, C. (1999) The causes of exclusion (London: Kogan Page)

Department for Children, Schools and Families (2009a) Pupil absence in schools in England including pupil characteristics: 2007/08. (London, DCSF)

Department for Children, Schools and Families (2009b) Permanent and fixed period exclusions from schools and exclusion appeals, England 2007/08.. (London: DCSF) 
Farrington, D. (1980) Truancy, delinquency, the home and the school, in L. Hersov, \& E. Berg. (eds). Out of school: Modern perspectives on truancy and school refusal. (Chichester: John Wiley)

Hallam, S. (1996) Improving School Attendance. (London: Heinemann)

Hallam, S., Ireson, J. \& Hurley, C. (2002) Ability grouping in secondary schools, relationships with attendance and exclusion. Paper given at the annual conference of the British Educational Research Association, September $10^{\text {th }}$ to $14^{\text {th }} 2002$ Exeter University, Exeter.

Hallam, S., Rogers, L. (2008) Improving behaviour and attendance at school. Maidenhead. McGraw Hill/ Open University Press

Hallam, S., Rogers, L., Rhamie, J., Shaw, J., Rees, E., Haskins, H., Blackmore, J., Hallam, J. (2007) Pupils' perceptions of an alternative curriculum: Skill Force. Research Papers in Education, 22(1), March, 43-63.

Hibbett, A. \& Fogelman, K, (1990) Future lives of truants: Family formation and health related behaviour. British Journal of Educational Psychology, 60, pp. 171-179.

Hibbett, A. \& Fogelman, K, (1990) Occupational outcomes of truancy. British Journal of Educational Psychology, 60, pp. 171-179. 
Munn, P., Lloyd, G., \& Cullen, M.A. (2000) Alternatives to exclusion from school (London: Paul Chapman Publishing)

O'Keeffe, D.J. (1994). Truancy in English Secondary schools (London: HMSO publications)

Osler, A., Watling, R., Busher, H., Cole, T., \& White, A. (2001) Reasons for exclusion from school. (London: DfEE)

Parsons, C. (1999) Education, Exclusion and Citizenship (London: Routledge)

Social Exclusion Unit (1998) Truancy and School Exclusion (London: The Stationery Office) 
Table 1: Percentage staff responses to statements about students' motivation, attitudes towards school, well-being and confidence

\begin{tabular}{|c|c|c|c|c|c|c|c|}
\hline $\begin{array}{l}\text { How successful has Skill Force } \\
\text { been in: }\end{array}$ & & $\begin{array}{l}\text { Very } \\
\text { Successful }\end{array}$ & Successful & $\begin{array}{l}\text { Quite } \\
\text { successful }\end{array}$ & $\begin{array}{l}\text { Relatively } \\
\text { unsuccessful }\end{array}$ & $\begin{array}{l}\text { No } \\
\text { impact }\end{array}$ & $\begin{array}{l}\text { Don't } \\
\text { know }\end{array}$ \\
\hline \multicolumn{8}{|c|}{ Motivation and attitudes towards school } \\
\hline \multirow{2}{*}{$\begin{array}{l}\text { Improving motivation } \\
\text { towards school } \\
\text { NS }\end{array}$} & $\begin{array}{l}\text { Skill } \\
\text { Force }\end{array}$ & $36 \%(21)$ & $41 \%(24)$ & $21 \%(12)$ & $2 \%(1)$ & & \\
\hline & $\begin{array}{l}\text { School } \\
\text { Staff }\end{array}$ & $26 \%(17)$ & $35 \%(23)$ & $28 \%(18)$ & $5 \%(3)$ & $2 \%(1)$ & $5 \%(3)$ \\
\hline \multirow{2}{*}{$\begin{array}{l}\text { Engendering positive } \\
\text { attitudes towards school } \\
\left(\mathrm{x}^{2}=12.6, \mathrm{df}=4, \mathrm{p}=.013\right)\end{array}$} & $\begin{array}{l}\text { Skill } \\
\text { Force }\end{array}$ & $22 \%(13)$ & $57 \%(33)$ & $21 \%(12)$ & & & \\
\hline & $\begin{array}{l}\text { School } \\
\text { Staff }\end{array}$ & $25 \%(16)$ & $32 \%(21)$ & $31 \%(20)$ & $9 \%(6)$ & & $3 \%(2)$ \\
\hline \multirow{2}{*}{$\begin{array}{l}\text { Positively changing students' } \\
\text { perceptions of the value of } \\
\text { education } \\
\text { NS }\end{array}$} & $\begin{array}{l}\text { Skill } \\
\text { Force }\end{array}$ & $35 \%(20)$ & $31 \%(18)$ & $31 \%(18)$ & $2 \%(1)$ & $2 \%(1)$ & \\
\hline & $\begin{array}{l}\text { School } \\
\text { staff }\end{array}$ & $14 \%(9)$ & $40 \%(26)$ & $34 \%(22)$ & $5 \%(3)$ & $3 \%(2)$ & $5 \%(3)$ \\
\hline $\begin{array}{l}\text { How successful has Skill Force } \\
\text { been in: }\end{array}$ & & $\begin{array}{l}\text { Very } \\
\text { Successful }\end{array}$ & Successful & $\begin{array}{l}\text { Quite } \\
\text { successful }\end{array}$ & $\begin{array}{l}\text { Relatively } \\
\text { unsuccessful }\end{array}$ & $\begin{array}{l}\text { No } \\
\text { impact }\end{array}$ & $\begin{array}{l}\text { Don't } \\
\text { know }\end{array}$ \\
\hline \multicolumn{8}{|c|}{ Well being and confidence } \\
\hline \multirow{2}{*}{$\begin{array}{l}\text { Promoting the well being of } \\
\text { students } \\
\text { NS }\end{array}$} & $\begin{array}{l}\text { Skill } \\
\text { Force }\end{array}$ & $36 \%(21)$ & $47 \%(27)$ & $12 \%(7)$ & & $2 \%(1)$ & $3 \%(2)$ \\
\hline & $\begin{array}{l}\text { School } \\
\text { staff }\end{array}$ & $40 \%(26)$ & $34 \%(22)$ & $15 \%(10)$ & $3 \%(2)$ & $2 \%(1)$ & $6 \%(4)$ \\
\hline \multirow[t]{2}{*}{$\begin{array}{l}\text { Raising self-confidence } \\
\left(\mathrm{x}^{2}=10.8, \mathrm{df}=4, \mathrm{p}=.029\right)\end{array}$} & $\begin{array}{l}\text { Skill } \\
\text { Force }\end{array}$ & $67 \%(39)$ & $28 \%(16)$ & $2 \%(1)$ & & & $3 \%(2)$ \\
\hline & $\begin{array}{l}\text { School } \\
\text { Staff }\end{array}$ & $46 \%(30)$ & $31 \%(20)$ & $15 \%(10)$ & $3 \%(2)$ & & $5 \%(3)$ \\
\hline \multirow[t]{2}{*}{$\begin{array}{l}\text { Improving social skills } \\
\mathrm{NS}\end{array}$} & $\begin{array}{l}\text { Skill } \\
\text { Force }\end{array}$ & $47 \%(27)$ & $41 \%(24)$ & $10 \%(6)$ & & & $2 \%(1)$ \\
\hline & $\begin{array}{l}\text { School } \\
\text { Staff }\end{array}$ & $28 \%(18)$ & $37 \%(24)$ & $25 \%(16)$ & $3 \%(2)$ & $2 \%(1)$ & $6 \%(4)$ \\
\hline \multirow{2}{*}{$\begin{array}{l}\text { Raising levels of self-respect } \\
\text { for people } \\
\left(\mathrm{x}^{2}=15.6, \mathrm{df}=5, \mathrm{p}=.008\right)\end{array}$} & $\begin{array}{l}\text { Skill } \\
\text { Force }\end{array}$ & $28 \%(16)$ & $55 \%(32)$ & $16 \%(9)$ & & & $2 \%(1)$ \\
\hline & $\begin{array}{l}\text { School } \\
\text { Staff }\end{array}$ & $13 \%(8)$ & $41 \%(26)$ & $28 \%(18)$ & $3 \%(2)$ & $6 \%(4)$ & $9 \%(6)$ \\
\hline \multirow{2}{*}{$\begin{array}{l}\text { Improving staff pupil } \\
\text { relationships } \\
\left(\mathrm{x}^{2}=15.2, \mathrm{df}=5, \mathrm{p}=.01\right)\end{array}$} & $\begin{array}{l}\text { Skill } \\
\text { Force }\end{array}$ & $31 \%(18)$ & $41 \%(24)$ & $26 \%(15)$ & & & $2 \%(1)$ \\
\hline & $\begin{array}{l}\text { School } \\
\text { Staff }\end{array}$ & $20 \%(13)$ & $34 \%(22)$ & $20 \%(13)$ & $9 \%(6)$ & $6 \%(4)$ & $11 \%(7)$ \\
\hline
\end{tabular}


Table 2: Percentage of staff responses to statements about the impact of Skill Force on behaviour, relationships with authority, discipline and attendance

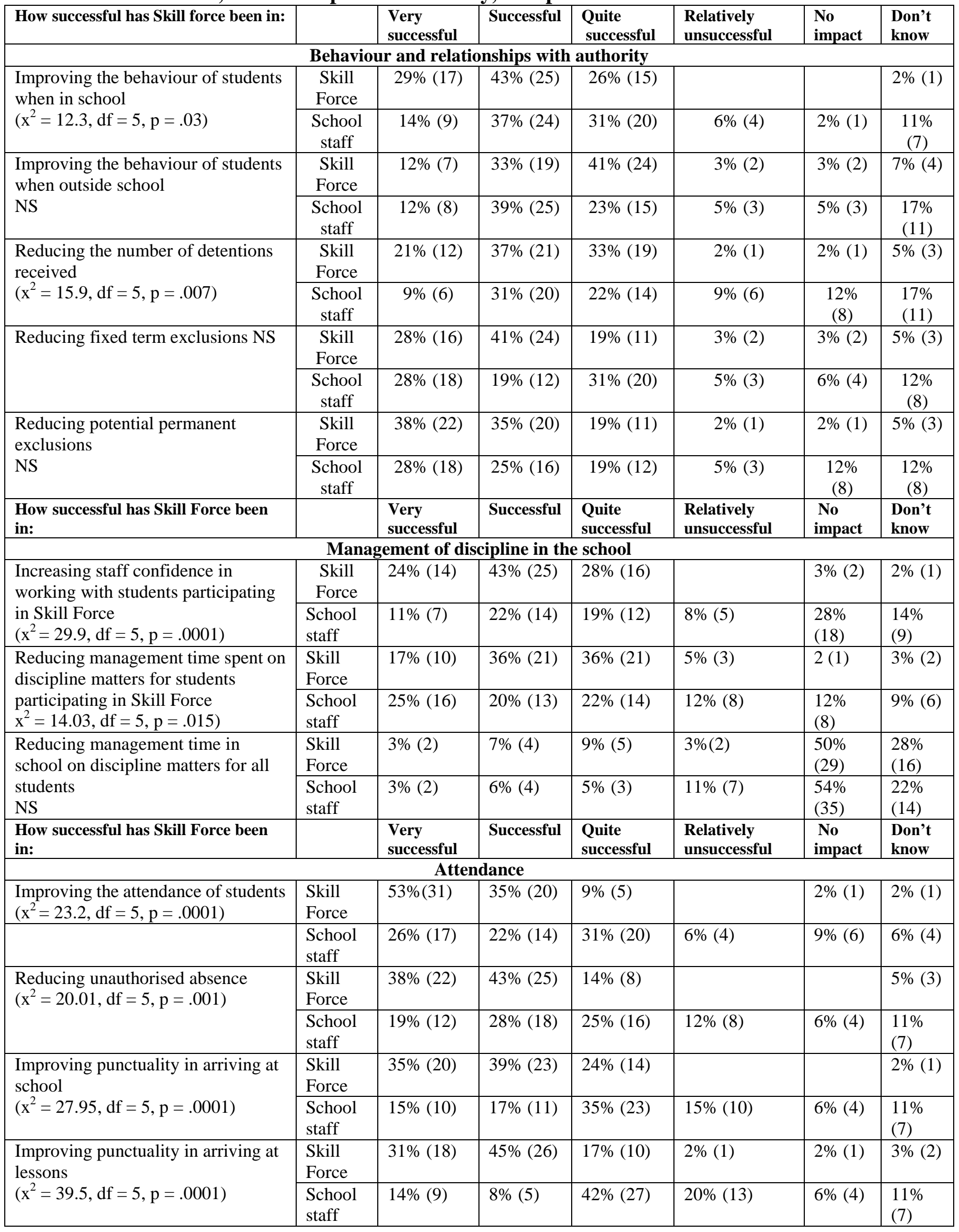




\section{Table 3: Staff perceptions of the impact of Skill Force on studying, performance and home-school relationships}

\begin{tabular}{|c|c|c|c|c|c|c|c|}
\hline $\begin{array}{l}\text { How successful has Skill } \\
\text { Force been in: }\end{array}$ & & $\begin{array}{l}\text { Very } \\
\text { successful }\end{array}$ & Successful & $\begin{array}{l}\text { Quite } \\
\text { successful }\end{array}$ & $\begin{array}{l}\text { Relatively } \\
\text { unsuccessful }\end{array}$ & No impact & $\begin{array}{l}\text { Don't } \\
\text { know }\end{array}$ \\
\hline \multicolumn{8}{|c|}{ Studying and performance } \\
\hline \multirow{2}{*}{$\begin{array}{l}\text { Improving concentration } \\
\text { on work } \\
\left(\mathrm{x}^{2}=3.88, \mathrm{df}=5, \mathrm{p}=\right. \\
.0001)\end{array}$} & $\begin{array}{l}\text { Skill } \\
\text { Force }\end{array}$ & $36 \%(21)$ & $40 \%(23)$ & $21 \%(12)$ & $2 \%(1)$ & & $2 \%(1)$ \\
\hline & $\begin{array}{l}\text { School } \\
\text { staff }\end{array}$ & $6 \%(4)$ & $35 \%(23)$ & $35 \%(23)$ & $11 \%(7)$ & $3 \%(2)$ & $9 \%(6)$ \\
\hline \multirow{2}{*}{$\begin{array}{l}\text { Improving } \\
\text { communication skills } \\
\left(\mathrm{x}^{2}=21.26, \mathrm{df}=5, \mathrm{p}=\right. \\
.001)\end{array}$} & $\begin{array}{l}\text { Skill } \\
\text { Force }\end{array}$ & $65 \%(38)$ & $28 \%(16)$ & $5 \%(3)$ & & & $2 \%(1)$ \\
\hline & $\begin{array}{l}\text { School } \\
\text { staff }\end{array}$ & $28 \%(18)$ & $40 \%(26)$ & $19 \%(12)$ & $3 \%(2)$ & $3 \%(2)$ & $8 \%(5)$ \\
\hline \multirow{2}{*}{$\begin{array}{l}\text { Improving listening skills } \\
\left(\mathrm{x}^{2}=18.6, \mathrm{df}=5, \mathrm{p}=\right. \\
.002)\end{array}$} & $\begin{array}{l}\text { Skill } \\
\text { Force }\end{array}$ & $53 \%(31)$ & $33 \%(19)$ & $14 \%(8)$ & & & \\
\hline & $\begin{array}{l}\text { School } \\
\text { staff }\end{array}$ & $22 \%(14)$ & $42 \%(27)$ & $23 \%(15)$ & $5 \%(3)$ & $2 \%(1)$ & $8 \%(5)$ \\
\hline \multirow{2}{*}{$\begin{array}{l}\text { Raising the standard of } \\
\text { work } \\
\left(\mathrm{x}^{2}=25.69, \mathrm{df}=5, \mathrm{p}=\right. \\
.0001)\end{array}$} & $\begin{array}{l}\text { Skill } \\
\text { Force }\end{array}$ & $38 \%(22)$ & $45 \%(26)$ & $16 \%(9)$ & & & $2 \%(1)$ \\
\hline & $\begin{array}{l}\text { School } \\
\text { staff }\end{array}$ & $17 \%(11)$ & $23 \%(15)$ & $37 \%(24)$ & $5 \%(3)$ & $8 \%(5)$ & $9 \%(6)$ \\
\hline \multirow{2}{*}{$\begin{array}{l}\text { Improving the GCSE } \\
\text { grades } \\
\text { NS }\end{array}$} & $\begin{array}{l}\text { Skill } \\
\text { Force }\end{array}$ & $2 \%(1)$ & $16 \%(9)$ & $36 \%(21)$ & $7 \%(4)$ & $10 \%(6)$ & $29 \%(17)$ \\
\hline & $\begin{array}{l}\text { School } \\
\text { staff }\end{array}$ & $3 \%(2)$ & $11 \%(7)$ & $19 \%(12)$ & $6 \%(4)$ & $14 \%(9)$ & $48 \%(31)$ \\
\hline \multirow{2}{*}{$\begin{array}{l}\text { Raising the career } \\
\text { aspirations } \\
\left(\mathrm{x}^{2}=19.6, \mathrm{df}=5, \mathrm{p}=\right. \\
.001)\end{array}$} & $\begin{array}{l}\text { Skill } \\
\text { Force }\end{array}$ & $38 \%(22)$ & $41 \%(24)$ & $19 \%(11)$ & & & $2 \%(1)$ \\
\hline & $\begin{array}{l}\text { School } \\
\text { staff }\end{array}$ & $15 \%(10)$ & $37 \%(24)$ & $20 \%(13)$ & $2 \%(1)$ & $6 \%(4)$ & $20 \%(13)$ \\
\hline \multirow{2}{*}{$\begin{array}{l}\text { Improving the career } \\
\text { opportunities for students } \\
\text { NS }\end{array}$} & $\begin{array}{l}\text { Skill } \\
\text { Force }\end{array}$ & $33 \%(19)$ & $43 \%(25)$ & $16 \%(9)$ & & $2 \%(1)$ & $7 \%(4)$ \\
\hline & $\begin{array}{l}\text { School } \\
\text { staff }\end{array}$ & $22 \%(14)$ & $35 \%(23)$ & $20 \%(13)$ & $2 \%(1)$ & $5 \%(3)$ & $17 \%(11)$ \\
\hline $\begin{array}{l}\text { How successful has Skill } \\
\text { Force been in: }\end{array}$ & & $\begin{array}{l}\text { Very } \\
\text { successful }\end{array}$ & Successful & $\begin{array}{l}\text { Quite } \\
\text { successful }\end{array}$ & $\begin{array}{l}\text { Relatively } \\
\text { unsuccessfu } \\
\text { l }\end{array}$ & $\begin{array}{l}\text { No } \\
\text { impact }\end{array}$ & $\begin{array}{l}\text { Don't } \\
\text { know }\end{array}$ \\
\hline \multicolumn{8}{|c|}{ Home-school relationships } \\
\hline \multirow[t]{2}{*}{$\begin{array}{l}\text { Enhancing parent-teacher } \\
\text { relationships }\end{array}$} & $\begin{array}{l}\text { Skill } \\
\text { Force }\end{array}$ & $14 \%(8)$ & $28 \%(16)$ & $33 \%(19)$ & $14 \%(8)$ & $2(1)$ & $10 \%(6)$ \\
\hline & $\begin{array}{l}\text { School } \\
\text { staff }\end{array}$ & $11 \%(7)$ & $20 \%(13)$ & $31 \%(20)$ & $8 \%(5)$ & $17 \%(11)$ & $14 \%(9)$ \\
\hline \multirow{2}{*}{$\begin{array}{l}\text { Encouraging greater } \\
\text { communication between } \\
\text { school and home } \\
\text { NS }\end{array}$} & $\begin{array}{l}\text { Skill } \\
\text { Force }\end{array}$ & $17 \%(10)$ & $29 \%(17)$ & $36 \%(21)$ & $5 \%(3)$ & $2 \%(1)$ & $10 \%(6)$ \\
\hline & $\begin{array}{l}\text { School } \\
\text { staff }\end{array}$ & $14 \%(9)$ & $29 \%(19)$ & $25 \%(16)$ & $8 \%(5)$ & $15 \%(10)$ & $9 \%(6)$ \\
\hline
\end{tabular}

